\title{
ХРИСТИЯНСЬКА КОНЦЕПЦІЯ ВЛАДИ ЯК ПЕРШОДЖЕРЕЛО ФОРМУВАННЯ ПОЛІТИКО-ПРАВОВОЇ ДОКТРИНИ ДОБИ СЕРЕДНЬОВІЧЧЯ
}

Забзалюк Д. $\epsilon$.

Ця стаття присвячена характеристиці християнської концепції влади, котра остаточно сформулювалась у період Середньовіччя. Досліджуються кілька підходів легітимації влади, серед яких виділяємо релігійний та релігійно-філософський. Аналізуються підходи видатних мислителів Середньовіччя, серед яких - Аврелій Августин, Фома Аквінський, Ансельм Кентерберійський, Сугерій, Папа Римський Урбан II, П'єр Абеляр та інші.

Аналізується теоретичний зміст християнської концепції влади, який однозначно випливає зі світогляду епохи та охоплює загальнотеоретичне вирішення державно-правових явищ та процесів. Вирішальними складниками змісту політико-правової доктрини є система категорій, які виконують роль функціональних засад тих чи інших доктринальних концепцій. Для доби Середньовіччя основним категоріальним змістом концепціі влади виступають ідеї непохитності церковної влади, домінування монархічної форми правління, яка 6 спиралась на владу Церкви, поєднання та ефективне співіснування звичаєвого, римського та канонічного права, які творять цілісну та домінуючу правову систему в загальноєвропейському масштабі. Фундаментальною основою християнської концепції влади у період Середньовіччя була програма, яка була визначальною в контексті оформлення політичних та правових поглядів. Головними методологічними складниками концепції влади в добу Середньовіччя, їі ідеологічною основою $є$ необхідність корінних змін суспільно-політичних відносин, що полягала у зміцненні авторитету церкви, який похитнувся.

У статті вказується на те, що концепція влади, заснована на християнській ідеології, складається на рубежі епохи Стародавнього світу та епохи Середньовіччя. Це релігійно-філософська легітимація влади. Якщо суто релігійний підхід апелював виключно до віри, то релігійно-філософський - $і$ до віри, $і$ до розуму: сформулювалися політичні теорії, створювалася складна система логічних доказів, вибудовувалася історична аргументація.

Ключові слова: християнство, влада, легітимація, релігія, концепція, середньовіччя, політико-правова доктрина.
Zabzaliuk D. Ye. The Christian concept of authority as the primary source of the formation of political and legal doctrine in the Middle Ages

This article is devoted to the characteristics of the Christian concept of power, which was finally formulated in the Middle Ages. Several approaches to the legitimation of power are studied, among which we distinguish religious and religious-philosophical. The approaches of prominent thinkers of the Middle Ages, including Aurelius Augustine, Thomas Aquinas, Anselm of Canterbury, Sugherius, Pope Urban II, Pierre Abelard, and others, are analyzed.

The article points out that the concept of power, based on Christian ideology, is formed at the turn of the Ancient World and the Middle Ages. This is a religious and philosophical legitimation of power. If the purely religious approach appealed exclusively to faith, the religious-philosophical one appealed to both faith and reason: political theories were formulated, a complex system of logical proofs was created, and historical argumentation was built. The basic axioms, of course, were accepted by faith. But even here the situation is more complicated than it may seem at first glance. Christianity, due to the division of theologians and the presence of a large number of different schools and areas, has created many opportunities for pragmatic choice. Useful, from the point of view of the author or school, truths were chosen from axioms. Thus, the religious and philosophical legitimation of power became a means to achieve political goals.

The article substantiates the thesis that the hierarchical principle is the most important feature of medieval society and an inevitable companion of any legitimation model. Royal power was thought of in the medieval West as part of this hierarchy subordinated to ecclesiastical power. And kings - the first among equals (the formula was voiced at the coronation). The primacy was that the monarchs had to "tame" their vassals, who did not want to occupy the level allotted to them in the social hierarchy.

Key words: Christianity, power, legitimation, religion, concept, Middle Ages, Political and legal doctrine.

( С Забзалюк Д. Є., 2020 
Постановка проблеми. 3 моменту появи перших цивілізацій, а значить і перших державних утворень, перед політичними структурами i їх ідеологами постала проблема теоретичного обґрунтування існування влади. За багатотисячолітню історію людства на світовій арені діяла величезна кількість держав. Вони не були статичні ні в політичному, ні в економічному, ні в ідеологічному планах. Як правильно зауважив В. Гурвіч: «Держава народжується один раз, але видозмінюється і трансформується багато разів» [4, с. 205]. І. Ісаєв пише про це так: «Феномен влади завжди привертав цікавість як правлячих, так i тих, ким правлять <...> i, будучи одним з головних соціальних стимулів, протягом століть постійно трансформувався, приймаючи все нові і нові форми і постійно потребуючи нових обґрунтувань і пояснень» [7, с. 9]. Незміненим залишається одне - прагнення будь-якої влади довести, що: а) влада необхідна; б) вона необхідна в тому вигляді, в якому існує.

Метою цієї статті $\epsilon$ дослідження християнської концепції влади, що сформувалась у добу Середньовіччя і являла собою елемент політико-правової доктрини.

Стан дослідження проблеми. Під час аналізу такої проблематики звертаємось до праць видатних мислителів середньовічної доби: А. Августина, Ф. Аквінського, А. Кентерберійського, Сугерія, П. Абеляра. У вітчизняній та зарубіжній історіографії відзначаємо також наукові розвідки В. Гурвича, А. Гуревича, В. Зеньковського, І. Іса-

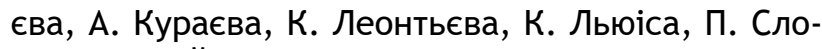
тердайка, Й. Хейзінги, М. Хомякова, Ф. Шаффа, М. Шейнмана, Дж. Янга та інших.

Виклад основних положень. Історія політичної думки знає кілька варіантів такого роду легітимації влади. Варіант, породжений християнством, складається на рубежі епохи стародавнього світу та епохи Середньовіччя. Це релігійно-філософська легітимація влади. Якщо суто релігійний підхід апелював виключно до віри, то релігійно-філософський - і до віри, і до розуму: сформулювалися політичні теорії, створювалася складна система логічних доказів, вибудовувалася історична аргументація. Основні аксіоми, звичайно ж, приймалися на віру. Але і тут ситуація складніша, ніж може здатися на перший погляд.

Християнство через розколотість теологів і наявність великої кількості різноманітних шкіл і напрямів створило безліч можливостей для прагматичного вибору. 3 аксіом вибиралися корисні, з точки зору автора або школи, істини. Так, релі- гійно-філософська легітимація влади стала засобом для досягнення політичних цілей.

Між прихильниками релігійної та релігійнофілософської легітимації влади довгий час йшли надзвичайно серйозні суперечки. По суті, це було відображення суперечок між тертуліанівською концепцією віри і правом на інтелектуальний пошук. Противники останнього стверджували, що оскільки існує Святе Письмо, то вже цей факт заперечує необхідність роботи людського інтелекту. Тут доречно згадати слова Еразма Ротердамського, який, дискутуючи з протестантськими авторами, що заперечували не тільки церковну атрибутику i iєрархію, а й філософські роздуми, сказав: «Ви питаєте, навіщо потрібна філософія для вивчення Писання?» - Відповідаю: «А навіщо потрібно для цього невігластво?» [8, с. 168].

Таким чином, дуже поступово вимоги раціонально обґрунтовувати i логічно аргументувати політичні моделі християнських держав породили середньовічні концепції влади.

За багатовікову історію європейської політичної думки до цієї теми зверталися безліч авторів. У дуже стислій формі ми спробуємо виділити основні етапи розвитку цієї проблеми у середньовічній західноєвропейській політичній думці. Через специфіку теми під словом «релігія» буде розумітися насамперед християнство.

Засновником західноєвропейської християнської традиції інтелектуального пошуку по праву вважається Аврелій Августин (354-430рр.), канонізований Римом. В. Зеньковський пише, що «якщо порівнювати, наприклад, «Сповідь» блаженного Августина з аскетичними письменниками Сходу (св. Макарій, св. Іоанн Ліствичник, св. Ісаак Сиріянин), то стає ясно, як далеко розійшлися християнський Схід і Захід у цій сфері» [6, с. 115].

Це була епоха кристалізації фундаментальних відмінностей. Тих самих відмінностей, що приведуть надалі до конфлікту: «Контакт між двома великими християнськими культурами, Західною і Східною, не міг не призвести до конфлікту між ними. Ці християнські культури були дуже різні в їхньому підході до багатьох метафізичних питань. Примирення думок західних і східних Отців Церкви $з$ цих питань може розглядатися як проблема толерантності» [13, с. 25]. Але це буде пізніше, в період Каролінгського відродження, коли західна латинська культура стикнеться з культурою грецького Сходу. Повертаючись до епохи, в яку релігійно-філософська думка виявила кристалізацію таких відмінностей, необхідно відзначити, що Аврелій Августин схильний був 
поділяти «світ земний» $\mathrm{i}$ «світ гірський» («град Божий») дистанцією, що нагадує непереборну прірву. Але з іншого боку, це не було примітивним ізоляціонізмом у сектантському стилі, а значить, не мало на увазі повне ігнорування питань облаштування «світу земного». Августин і владу розумів як силу, перш за все впорядковуючу і організуючу соціальну реальність, що відповідає на «вселенський виклик хаосу». Саме на цьому базуються уявлення Августина про законослухняність, про необхідність підпорядкування народу керуючим, а рабів - «панам своїм».

Одним з віддалених (у часовому сенсі) послідовників Аврелія Августина був систематизатор ортодоксальної схоластики Фома Аквінський. Що стосується нашої теми, слід зауважити, що концепція влади і у Августина, і у Фоми прямо протилежні. У питаннях владної проблематики Аквінський набагато ближчий до того ж Аристотеля, ніж до Августина.

Чималий внесок зробив Фома Аквінський i у справу розгляду питання про взаємини церкви зі світською владою. Так, один з творів цього автора, написаний у 1263 році, створювався «князем теологів» за спеціальним замовленням римської курії для Папи Урбана IV. Квінтесенцію цього трактату дуже добре висловив М. Шейнман, сказавши: «Фома Аквінський доводив, що римський Папа перший і найбільший серед єпископів, що папський престол - це влада, яку Христос дав апостолу Петру» [15, с. 64-65]. Не випадково католицькі теологи, що фіксували в новий час догмат про папську непогрішність, так активно посилалися на Фому Аквінського.

У Святому Письмі - фундаменті християнської доктрини - ми не знаходимо суворої концепції влади або чіткого визначення держави. Про ці проблеми (особливо в новозавітній літературі) говориться уривками, часто трапляються туманні висловлювання. Але саме ці висловлювання становлять базу політичних моделей, сформульованих середньовічними авторами.

Перша причина такої малої уваги до теми влади полягає в тому, що будь-яка релігія відповідає перш за все на три питання: Що таке Бог? Що таке людина? Як вони пов'язані один з одним? Усі інші питання носять другорядний характер.

Друга причина полягає в тому, що відносини між державою і релігійною громадою починають вибудовуватися тоді, коли в цьому виникає історична необхідність. Іншими словами, громада повинна вирости кількісно і якісно, тоді у неї виникне потреба налагодження взаємин з вла- дою, і тоді вона буде формулювати свій погляд на владу та їі легітимацію.

Сам засновник християнського віровчення дуже мало говорив про державу. Судячи з євангельської літератури, це, найчастіше, були відповіді на питання, які надходили від «іудейської інтелігенції». Представники іудейської релігійної та політичної еліти досить наполегливо намагалися зіштовхнути Ісуса з римською владою, що їм, зрештою, хоча і з труднощами, але вдалося. Насилу, бо він ніколи не виступав проти державної влади загалом і Риму зокрема. Навпаки, «перший християнин» надзвичайно коректно відгукувався про владу, що дає привід для тверджень, ніби християнська концепція влади має своєю основою сліпу покірність.

Люди, на думку Христа, повинні прагнути до ухилення від державної посади. Це можливо лише в тому разі, коли посада - тягар. Так виникло унікальне християнське ставлення до влади: не як до нагороди, а як до важкої, виснажливої, небезпечної праці.

Що ж стосується питання покірності, то воно більшою мірою розроблялося учнями, ніж учителем. Це зрозуміло. Саме перед учнями постало завдання виробити ставлення до влади, бо вони бажали продовжувати «справу вчителя», а влада вже звернула свою увагу на це. Епоха, про яку писав П. Слотердайк («Бути християнином колись означало не симпатизувати жодній владі...») [10, с. 5], закінчилася. Тепер потрібно було засвідчувати владі свою лояльність.

У цьому сенсі християнська концепція влади базується скоріше на позиціях прагматизму: «Ієрархія - неодмінний атрибут будь-якої влади. Часом важко визначити, що $є$ первинним у цій парі, проте нерозривне існування обох феноменів. Говорячи про структурування влади, мають на увазі перш за все іï ієрархію. Інший сенс того ж висловлювання зводиться до ототожнення ієрархії з організацією влади: влада принципово не може не бути організованою, хоч би якими непомітними і скритними були ії механізми...» [7, с. 99]. Але влада структурована тому, що структуроване суспільство.

Аналізуючи доробок Аврелія Августина, П. Слотердайк справедливо зазначив, що керуючись працями цього автора, можна дійти висновку: та організація, яку має на землі церква, має своїм джерелом небеса, де вона примикає до божественних сфер і вже потім простягається від них до самої землі $[17$, с. 285]. Церква, з точки зору християнської релігї̈, є деякою мірою «моделлю» 
суспільства. Соціальна ієрархія в цьому плані $\epsilon$ відображенням церковної ієрархії на земному пласті реальності.

Фома Аквінський вважав, що в розумі Творця присутні ідеї всіх речей і явищ світу. Ідея знаходить своє втілення в творінні, тобто знаходить плоть. Виходячи з цього, Фома стверджував, що ідея ієрархії виявляє себе ще в подіях, що описуються в Книзі Буття. На думку «князя теологів», вселенський статус істот відбився в місці їх творіння: ангели створені в «емпірії», людина в раю, тварини - на землі [11, с. 185].

Поширеною помилкою $\epsilon$ асоціювання станових відмінностей 3 відмінностями, побудованими виключно за принципом привілейованості. Грубо кажучи: стани діляться на «експлуататорів» i «експлуатованих». Але різниця соціальних статусів у середньовіччі мислилася як різниця у соціальних функціях. Досить згадати знамениту середньовічну формулу: одні - працюють, інші воюють, треті - моляться.

Як приклад найкраще взяти відношення середньовічних західних мислителів до військових. Людина, що належала до цієї групи (феодал), могла користуватися працею інших людей. Це вважалося природним. Але в разі, коли державі сеньйора, а значить і населенню, загрожувала небезпека, військовий повинен був виступити на його захист, ризикуючи здоров'ям і життям. Так звані «люди праці» були позбавлені цього обов'язку.

На нашу думку, «культ лицарства» був створений у середньовіччі саме тому, що через специфіку справи лицар жертвував суспільству не продукти фізичної праці, але життя і здоров'я. Згідно з абсолютно справедливим судженням П. Слотердайка, культ воїна виник тому, що боягузтво зустрічається в достатку: «Героїка була i залишається якоюсь мірою аж до сьогоднішнього дня домінуючим культурним фактором <...> Образ героя безжально нав'язується як високий зразок <...> Герой гріється в променях слави, йому - напівбогу війни - випадають усі почесті, вся суспільна хвала і всі найвищі оцінки соціуму» $[17$, с. 288]. Таким чином, воїн ставився на щабель вище за селянина середньовічними авторами не тому, що був кращим «за визначенням», а тому що виконував більш ризикову соціальну функцію.

Але з точки зору середньовічних авторів «людей хреста» i «людей меча» розділяє ще вищий щабель. Тут виявили себе потужні теократичні амбіції католицької церкви, які не могли не вплинути на міць королівської влади. Ця лінія, котра вперше виявила себе ще у IX столітті, була аргументована два століття потому. Зробив це представник ранньої схоластики, глава монастирської школи в Равені (Північна Італія), кардинал Петро Даміані. Даміані насамперед відомий тим, що сформулював знаменитий принцип: філософія - служниця теології. Але цей же автор висунув i інше гасло: священство вище царства.

У цьому ж напрямі працював і інший західний філософ - Ансельм, архієпископ Кентерберійський. Цей мислитель, якого прийнято вважати засновником схоластики, написав низку творів («Диктат Папи» та ін.), де підтримував лінію Григорія VII - одного з тих пап, що намагалися втілити в політичну реальність постулат про пріоритетність духовної влади над світською, бо церква $\epsilon$ сила, котра легітимізує владу. Головною ідеєю цих творів був погляд на римського понтифіка як на сеньйора всіх християнських монархів.

Слід додати, що слова у Ансельма Кентерберійського не розходилися зі справою. Народжений у П'ємонті (Італія), він довгий час фактично очолював англійську церкву, вів запеклу боротьбу з королями Вільгельмом Рудим і Генріхом I Англійським, котрі були виразниками цезаропапіських амбіцій. Ансельм відстоював церковний варіант інвеститури: єпископів і абатів призначати повинен Папа, а не король.

Ну а вінцем цього напряму в політичній думці західного середньовіччя стала творчість засновника томізму і систематизатора ортодоксальної схоластики, «ангельського доктора» Фоми Аквінського. Фома вибудував чітку ієрархічну систему: влада Папа - від Бога, влада королів - від Папи. Цей момент надзвичайно важливий для нашого дослідження з трьох причин.

По-перше, він остаточно закріплює за католицькою церквою і Папою як главою церкви функцію легітимації світської влади.

По-друге, він применшує владу світських правителів. Це ще раз підтверджує слова російського дослідника А. Гуревича про те, що на середньовічному Заході «склався принцип <...> абсолютно чужий доктрині про необмежену владу князя» [5, с. 171]. Слід тільки додати світського князя. По-третє, він наочно показує прагнення Фоми Аквінського ієрархізувати не тільки соціальну, але й політичну сферу. Але був у цього філософа i аргумент естетичного плану. Фома писав, що «досконалість всесвіту вимагає, щоб у речах була присутня нерівність» [11, с. 181].

Надзвичайно показовими в цьому контексті виглядають праці абата Сугерія, чиє ім'я може бути поставлено в один ряд з такими іменами, 
як кардинал Ришельє, адже абат був найближчим сподвижником короля Людовика VI Товстого і був фактичним правителем Франції при Людовіку VII. Будучи не просто видатним державним діячем, але ще і тонким політичним мислителем, абат Сугерій писав: «Священний обов'язок королів - могутньою рукою приборкувати зухвалість тиранів, які роздирають країну нескінченними війнами, потішаються грабежами, гублять бідний люд, розорюють церкви і настільки віддаються безумству, що якщо давати їм волю, воно розпалює їх усе більшою і більшою люттю» [1, с. 241].

Католицька ж свідомість сміливо брала на себе тягар соціально- політичного конструювання тіла людства, причому в глобальному масштабі. Тут досить навести приклад Папи Римського Урбана II - головного ідеолога Першого хрестового походу. На нашу думку, жодна релігія, за винятком середньовічного католицизму, не ставила перед собою завдання перетворення соціального тіла людства». У цій своїй частині середньовічна західноєвропейська концепція влади окреслює модель побудови «царства Божого» на землі у вигляді встановлення єдиної теократичної держави під зверхністю Папи.

Це, втім, не означає, що католицькій теорії влади властивий утопічний характер. Скоріше навпаки. Особливості політичної думки на тому чи іншому просторово-часовому відрізку багато в чому визначаються специфікою національно-історичної психології, «моделлю світу» того чи іншого цивілізаційного типу. Як зауважив свого часу І. Ільїн: «Тривале і уважне вивчення релігії переконало мене в тому, що всі релігії і конфесії відрізняються одна від одної не тільки догмами, обрядами і організацією, але і душевною своєрідністю віруючих...» [16, с. 170].

Застосовуючи цей підхід до богословсько-філософської думки середньовічного Заходу, ми можемо виділити потужне раціоналістичне начало, прагнення до розумових форм, жорстких логічних схем. Усе це повинно було породити (і породило) надзвичайно цілісну, монолітну «картину світу». Не випадково навіть затяті критики Заходу з числа слов'янофілів відзначали, що католицизм позбавлений будь-яких сильних внутрішніх протиріч [9, с. 19].

Але будь-який керівник, з точки зору західних авторів, повинен спиратися насамперед на силу закону. Тим більше, що, на думку багатьох, наприклад абата Сугерія, закон - це один з найважливіших факторів, що працює на національну єдність, який виправдовує існування влади в очах підданих. I тут ми виходимо, можливо, на найважливішу відмінну рису західноєвропейської політичної свідомості епохи Середньовіччя. Ця риса «юридизм».

Юридизм має під собою деяку (хоча і незначну) біблійну основу. В новозавітній літературі багато говориться про законослухняність і покору волі людей, які уособлюють закон. Міркувань тут може бути кілька. Перше міркування - морального характеру. Будь-яка влада - від Бога. Це фундамент середньовічної легітимаційної моделі. Підкоряючись владі, підкоряєшся Богу.

Однак для християнської думки характерний реалістичний погляд на світ. Безумовно, тільки незначна частина людей здатна суворо дотримуватися закону, керуючись високими моральними принципами. Християнство стверджує, що їх не так уже й мало.

У західній політичній теорії Середньовіччя ідея законослухняності і покори була першочерговою. Поступово закон ставав первинним, а людська особистість вторинною. У XII столітті П. Абеляр писав, що навіть у разі, коли невинуватість обвинувачуваного очевидна, але факти формально проти нього, то обвинуваченого необхідно карати в ім'я закону [2, с. 166-167]. Так, принцип «закон для людини» виявився замінений іншим - «людина для закону».

Дослідник середньовічної культури Й. Хейзінга писав: «Ця епоха не знає такої спонукальної причини думок і вчинків людей, як свідоме прагнення до покращення та перетворення суспільних або державних справ. Навіть якщо у формах суспільного життя і з'являється щось нове, це розглядається лише як відновлення доброго, старого права або ж як припинення зловживань» [12, с. 39].

Звідси те відчуття високої відповідальності, яке намагалися прищепити середньовічні автори політичним діячам, які беруться за суспільні перетворення. 3 іншого боку, священним обов'язком підданих $\epsilon$ підпорядкування тим нововведенням, які слідують з боку влади. Процитуємо ще раз Аврелія Августина: «Цар земний має право в державі, ним керованої, давати такі укази і веління, яких до нього і при ньому раніше не було; i, якщо, підкоряючись йому, не порушують правил взаємного союзу державного, а навпаки, порушують ці правила: адже головна умова взаємного союзу у будь-якій державі полягає в покорі царям і взагалі вищій владі» [3, с. 58].

Висновки. Середньовічні західні теоретики влади здебільшого відстоювали ідею, котра розглядала апарат держави як інструмент примусу. 
Цей апарат, з одного боку, пов'язаний із суспільством, а з іншого - знаходиться на певній відстані. Адже «суб'єкт» повинен бути на дистанції від об'єкта примусу. Але закони можуть змінюватися, як може змінюватися сама держава. У християнській свідомості (на відміну, скажімо, від античної) присутнє відчуття історії як руху, процесу. Вона (ця свідомість), безумовно, досить консервативна.

\section{Література}

1. Аббат Сугерий. Из работы «0 жизни короля Людовика Толстого». Хрестоматия по истории средних веков. / под ред. Степанова В.Е., Шевеленко А.А. Москва, 1980. Т. 1. 188 с.

2. Абеляр П. Этика, или Познай самого себя. Теологические трактаты. Москва, 1993. С. 166-167.

3. Августин Блаженный. Исповедь. Творения Блаженного Августина. Москва : Рипол Классик. 2019. 417 c.

4. Гурвич В. Национальная идея и личность. Новый мир. 1993. № 5. С. 205-208.

5. Гуревич А.Я. Категории средневековой культуры. Москва : Искусство, 1984. 350 с.

6. Зеньковский В. Принципы православной антропологии. Русское зарубежье в год тысячеле тия крещения Руси. Москва, 1991. С. 115-148.

7. Исаев И.А. Politica hermetica: скрытые аспекты власти. Москва : ЮРИСТъ, 2002. 411 с.

8. Кураев А. Трудное восхождение. Новый мup. 1993. № 6. С. 162-182.
9. Леонтьев К.Н. Византизм и Славянство. Москва, 2005. 278 с.

10. Льюис К. Просто христианство. Чикаго : SGP, 1990. 217 c.

11. Фома Аквинский. Из «Суммы теологии». Из произведений Фомы Аквинского (приложение к работе Боргош Ю. «Фома Аквинский»). Москва, 1966. С. 143-176.

12. Хейзинга Й. Осень Средневековья. Москва : «Наука», 1988. 544 с.

13. Хомяков М.Б. Толерантность и современная цивилизация. Екатеринбург : Изд-во Урал. ун-та, 2000. $112 \mathrm{c}$.

14. Шафф Ф. История Христианской церкви. / Пер. с англ. О.А. Рыбакова. Санкт-Петербург : Библиотека для всех, 2008. T. V. Средневековое христианство. 574 с.

15. Шейнман М.М. Католицизм в меняющемся мире. Москва, 1975. 161 с.

16. Янг Дж. Христианство. / пер. с англ. К. Савельева. Москва : ФАИР-ПРЕСС, 2001. 384 с.

17. Sloterdijk P. Kritik der zynischen Vernunft. Frankfurt am Main, 1983. 118 p.

Забзалюк Д. $\epsilon$., кандидат історичних наук, доцент, завідувач кафедри теорії та історії держави і права, конституційного та міжнародного права Львівського державного університету внутрішніх справ 